\title{
Gossiping in Hawthorne's The Scarlet Letter (1850)
}

\author{
Zahraa Adnan Fadhil Al- Murib \\ Department of English, College of Education for Human Sciences \\ Islamic University, Hilla, Iraq
}

\begin{abstract}
This study deals with gossiping as a complex speech act carried out through multiple participants. It can include many speech acts and can fit into various speech act categories. Thus, this study aims at (1) investigating the most common speech acts used - in order to issue gossiping, (2) figuring out the most common types of presupposition of gossiping, and (3) identifying the functions of gossiping. To achieve these aims, it is hypothesized that: (1) stating and telling are the most common speech acts used in issuing gossiping, (2) factive presupposition is the most common type used in issuing gossiping, and (3) information, intimacy, and entertainment are the functions of gossiping. Then, to achieve the aims of the study and test its hypotheses, the following procedures are adopted: (1) presenting a theoretical background of gossiping, and (2) analyzing the data of the study according to a model developed by the study. The findings of such analysis come up with employing different kinds of speech acts in triggering the gossip, on the part of the gossiper, such as: telling $(0.4 \%)$, stating $(0.4 \%)$, and criticizing $(0.2 \%)$. As for presupposition, it is the only strategy that is employed by the gossipers to trigger gossip in all of the ten excerpts. Depending on the analysis of the data of the study, the following conclusions are introduced: (1) Gossiping is an activity that is concerned with the affairs of a third party. (2) The speech acts of telling, stating, and criticizing are employed to trigger gossip. (3) Telling and stating, as pragmatic strategies, are connected with serving the function of conveying information.
\end{abstract}

Key words: Gossip, speech acts, presupposition, pragmatic strategies, The Scarlet Letter

Cites as: Al- Murib, Z. A. F. (2019). Gossiping in Hawthorne's The Scarlet Letter (1850). Arab World English Journal for Translation \& Literary Studies, 3 (3) 211-220.

DOI: http://dx.doi.org/10.24093/awejtls/vol3no3.17 


\section{Introduction}

Though, traditionally despised as being idle talk, gossiping could be indeed of value as a means of transmitting information. Today, it is seen as an innocuous activity and a way of venting with friends. However, it continues to have a moral string. That is, being known as a gossiper is not an identity desired by people (Tracy \& Robles, 2013, pp. 104-5).

Etymologically speaking, the term 'gossip' descends from Old English god sib which means kinsman or related and it characterizes someone who had a close relationship with the family. In Middle English, the word referred to a godparent who was someone acting as a sponsor at a baptism, or being a friend of. It also described "the woman who attended a birth with a midwife who was subsequently sent out following the birth to make the event known to others." In the middle ages, it is said that the situation was gossipy and censure of gossip flourished (Iterson, et al., 2011, p. 375; Eckert \& McConnell- Ginet, 2013, p. 109).

\section{Definition}

It is difficult to present a scientific definition of gossiping because it seems to be an ephemeral activity in addition to its being closely related to other forms of organizational discourse, such as myths, stories, rumor, small talk, chitchat, urban legends and so on. However, it is defined according to different perspectives.

Gossiping is defined as news about the affairs of others, or those of one's own, or any hearsay of a personal nature, either positive or negative [Fine and Rosnow (1976, P. 87) as cited in Frost, 2016, 31]. There seems to be two main elements to gossip. The first is concerned with the exchange of the information: only a limited number of people, no more than two or three, can take part in a serious gossip. Moreover, the level of gossiping deteriorates as the group expands. The second theme is that "the gossip always involves talk about one or more absent figures" (Spacks, 1986, p. 4) as cited in Frost, 2016, p. 31].

According to the anthropological perspective, Paine (1967, p. 279) as cited in Marcus (2010, p. 89)] defines gossiping as an informal device serving to forward and protect individual interests where it functions individually rather than socially. For Paine, gossip is a self- serving tool as it degrades others and strives to develop the status of the gossiper at the expense of the gossipee (Paine (1967, p. 279).).

Rosnow \& Fine (1976, p. 87) speak of gossiping as "news about the affairs of another, to one's own memoirs or confessions, or to any hearsay of a personal nature, be it positive or negative, spoken or in print." This social psychological perspective refers to self- disclosure (Iterson et al., 2011,p. 376).

Gossiping has been defined also from the sociological perspective by (Eder \& Enke (1991, p. 494) as cited in Underwood (2003, p. 144)] who define it as "evaluative talk about a person who is not present." It starts with an explicitly evaluative statement and others present are likely to agree with and elaborate on the negative evaluation.

Arab World English Journal for Translation \& Literary Studies 
A final inclusive definition is presented which mentions that gossiping is an 'exchange of personal information in an evaluative way about absent third parties.' (Foster (2004) as cited in Iterson et al., 2011, p.377).

\section{Types}

There are two types of gossiping: praise (positive) and blame (negative).

\subsection{Praise Gossiping}

Praise gossiping is a fundamental prerequisite of the human condition. It plays a number of different roles in the own group, the most important of which is simple social bonding. In other words, it strengthens the internal ties within the own group. It also reinforces group values. Additionally, within this own group, gossip takes the role of knowledge catalyst because it is 'a mechanism of information exchange.' As such, it can be spoken of as a constructive type since it augments a person's reputation (Soeters \& Iterson, 2002, p. 25; Ogden, 2017, n.p.).

\subsection{Blame Gossiping}

Blame gossiping entails a reproduction of false knowledge about an absent third person. It depends on the unproved testimony of the gossiper who is usually indifferent of the veracity of his claims, let alone the harm done. Blame gossip also presupposes a prejudice or stereotype about the third party harming and diminishing the testimony of its reputation. In addition, it reinforces unnamed and untested norms, where a norm means 'an element of the basis of which a certain exercise of power is founded and legitimized.' As such, blame or negative gossip is inherently destructive although the harm it causes can be underestimated or ignored (Ogden, 2017, n.p.).

\section{Functions of Gossiping} entertainment.

Gossiping serves different functions, namely, acquiring information, influence, and

\subsection{Information}

Gossiping functions as an information grapevine in situations that are personal or impersonal. In these situations, the need for news is great. It should be taken as a potential source of information in which participants work together to impart knowledge (Ogden, 2017, n.p.). This function of gossip challenges the assumption that the informational content of gossip is highly unreliable since it is an intrinsically valuable activity satisfying the basic need to acquire information about intimate aspects of other people's lives (Zimmerman, 2000, p. 338).

\subsection{Influence}

Gossiping serves another crucial function which is that of influence. It satisfies social control. That is, it provides the opportunity to receive and send opinions and evaluations that are about norm- relevant standards and departures there from, improper behavior, inappropriate dress, inopportune timing, and the like by one or more third parties (Goldstein, 2002, p. 46). 
Gossiping facilitates the conservation of social norms, i.e. "the individuals fearing that they will be the target of gossip if they behave badly may be less likely to act in socially inappropriate ways. Thus, gossiping may serve as informal social control" (Crawford \& Novak, 2014, p. 442).

\subsection{Entertainment}

Gossiping can also entertain, be it a "satisfying diversion" or "intellectual chewing gum." It breaks monotony in certain work places [Foster, 2004, p. 86 as cited in Al- Hindawi \& AlKhazaali, p. 138)]. It serves no more than a way of passing some redundant time between individuals. Most importantly is that the entertainment value of gossip occurs outside the actual exchange (Foster, 2004, p. 86 as cited in Al- Hindawi \& Al- Khazaali, p. 138)].

\section{Speech Acts}

As pragmatic components, speech acts are considered important for Gossip. A speech act is an act performed when making an utterance. Several categories of speech acts have been proposed. Austin (1962) argues that there are three types of acts standardly performed when making utterances: locutionary, illocutionary, perlocutionary act. These three types are described in the following way (as cited in Schiffer, 2008, p. 351):

(1) The locutionary act is an act of saying involves, when performed, uttering noises (the phonetic act) belonging to a certain vocabulary and conforming to a certain grammar (the phatic act), and with a certain sense and reference, together are typical to meaning (the rhetic act). In addition, when performed, this locutionary act is determined by what the performer meant (Austin, p. 92-100) as cited in Schiffer, 2008, p. 351).

(2) The illocutionary act is the act that is opposed to the act of saying, i.e. it is the act that one performs in doing something. It consists of the delivery of the propositional content of a particular utterance and a certain illocutionary force whereby the speaker performs the act with non- verbal means, like warning and protesting (Austin, p. 92-100) as cited in Schiffer, 2008, p. 351).

(3) The perlocutionary act is the act that is performed by uttering something, i.e. the act that produces an effect on the hearer. This act is intrinsically related to the illocutionary act which precedes it, but it can be differentiated from it and be discrete (Galber, 2002, p. 56).

According to Crystal (2008, p. 446), the speech acts fall into five categories:

(1) Directivees: speakers try to get their lisiners to do something, e.g. begging, commanding, requesting.

(2) Commissives: speakers perpetrate themselves to future course of actions, e.g. promising, guaranteeing.

(3) Expressive: speakers express their feelings, e.g. apologizing, welcoming, sympathizing.

(4) Declarations: speakers bring about a new external situation by their utterances, e.g. christening, marrying, resigning).

Arab World English Journal for Translation \& Literary Studies 
(5) Representatives: speakers convey their belief about the truth of a proposition, e.g. asserting, hypothesizing.

\section{Presupposition}

Another pragmatic component that is important to the activity of gossip is presupposition. To presuppose is to posit a proposition as valid. Preposition is concerned with knowledge that is presumed to be part of the background of the sentence and known for both the addressee (Hudson, 2000, p. 322).

There are several attempts at the classification of presuppositions. One of them is that of Short (1989) (as cited in Mazid, 2014, p. 57). He classified presuppositions into: existential, linguistic, and pragmatic, whereas Yule (1996) ( as cited in Mazid, 2014, p. 57) classified them into existential, factive, lexical, structural and non- factive. The latter classification is described as follows (Yule (1996) as cited in Mazid, 2014, p. 57):

(1) The existential: it is triggered by definite noun phrases and possessives, the sentence his car is red presupposes that (there is a car that is his).

(2) The factive: it is triggered by:

a. factive emotive verbs, e.g., she is glad that her son got the prize (her son got the prize).

b. factive epistemic verbs, e.g., I realize that I was driving fast (I drove fast).

(3) The lexical: it is triggered by:

a. implicative verbs, e.g., he forgot to close the door (he ought to have closed the door).

b. inchoative (change of state verbs), e.g., he stopped beating his wife (he used to beat her).

c. iterative, e.g., he didn't come again (he came before).

d. judging verbs, e.g. she criticized him for running away (he ran away and this was bad).

(4) The Structural: it is triggered by:

a. temporal clauses, e.g., when I drove fast, I skidded (I had been

driving fast)

b. cleft and pseudo- cleft sentences, e.g. what Mary lost was her

handbag (Mary lost something).

c. questions, e.g. did he leave? (he either left or didin't leave).

d. non- restrictive relative clauses, e.g., Ahmed, who was absent yesterday, is still sick (he is sick).

(5) The non-factive: it is triggered by non- factive verbs, e.g., he pretends to be ill (he is not ill).

\section{The Model}

The model that is taken to serve the aims of this study is the communicative model of Braddock (1958). The latter presented a communicative formula including a number of elements.. Thus, and along with the observations made by the researcher, the model of the study 
is modified in such a way that suits the pragmatic analysis of the data of the study, as it is shown in the following figure:

\section{The Pragmatic Analysis of Gossip}

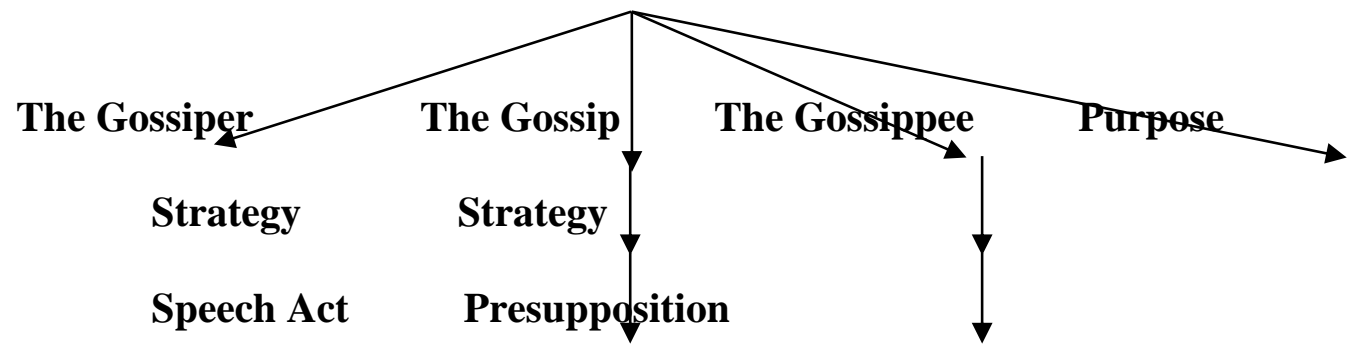

Figure 1. The Developed Model of the Study

\section{Data Collection and Data Analysis \\ 8.1 Data Collection}

The data of this study are set to be ten excerpts taken from the romance novel The Scarlet Letter (1850) by Nathaniel Hawthorne.

\subsection{Data Analysis}

The excerpt to start with is:

"Goodwives," said a hard-featured dame of fifty, "I'll tell ye a piece of my mind. It would be greatly for the public behoof, if we women, being of mature age and church-members in good repute, should have the handling of such malefactresses as this Hester Prynne." (Hawthorne, 1852, p. 46)

The hard-featured dame, the gossiper, starts the gossip by using the speech act of telling to convey information. The gossipee is realized by existential presupposition which is triggered by the definite noun phrase, Hester Prynne.

\section{Excerpt 2:}

"People say," said another, "that the Reverend Master Dimmesdale, her godly pastor, takes it very grievously to heart that such a scandal should have come upon his congregation." (Hawthorne, 1852, p. 46)

The gossipper is another dame who starts the gossip by utilizing the speech act of stating to achieve influence as the gossip includes talking about norm- relevant standards. The gossiper is master Dimmesdale. It is triggered by existential presupposition (a definite noun phrase). 


\section{Excerpt 3:}

"The magistrates are God-fearing gentlemen, but merciful overmuch,--that is a truth," added a third autumnal matron. (Hawthorne, 1852, p. 47)

The gossiper is a matron activating the gossip by an explicit speech act of stating to convey information. The gossiper is the magistrates triggered by existential presupposition (a definite noun phrase).

\section{Excerpt 4:}

"What do we talk of marks and brands, whether on the bodice of her gown, or the flesh of her forehead?" cried another female, the ugliest as well as the most pitiless of these self-constituted judges. "This woman has brought shame upon us all, and ought to die." (Hawthorne, 1852, p. 46)

The gossiper is a female. The gossip is figured in the shape of an implicit criticizing of the gossipee who is triggered by the existential presupposition (a noun phrase). This gossip serves the purpose of influence as it is concerned with improper behavior.

\section{Excerpt 5:}

"She hath good skill at her needle, that's certain," remarked one of the female spectators; "but did ever a woman, before this brazen hussy, contrive such a way of showing it! Why, gossips, what is it but to laugh in the faces of our godly magistrates, and make a pride out of what they, worthy gentlemen, meant for a punishment?" (Hawthorne, 1852, p. 49)

The gossiper is a female spectator. She presents the gossip by an implicit criticizing of the brazen hussy (the gossipee that is presented by employing the existential presupposition). This gossip serves to impart knowledge.

\section{Excerpt 6:}

"You must needs be a stranger in this region, friend," answered the townsman, looking curiously at the questioner and his savage companion; "else you would surely have heard of Mistress Hester Prynne, and her evil doings." (Hawthorne, 1852, p. 56)

The gossiper is the townsman. He triggers the gossip by the speech act of telling to convey information. The gossipee is actuated by the existential presupposition (definite noun phrase).

\section{Excerpt 7:}

"... Yonder woman, Sir, you must know, was the wife of a certain learned man, English by birth, but who had long dwelt in Amsterdam, whence, some good time agone, he was minded to cross over and cast in his lot with us of the Massachusetts." (Hawthorne, 1852, p. 56)

The gossiper is the townsman. The gossip is actuated by the speech act of stating which is utilized to impart knowledge. The gossipee is the yonder woman (noun phrase) that is presented by the existential presupposition. 


\section{Excerpt 8:}

the children of the Puritans looked up from their play,--or what passed for play with those sombre little urchins,--and spake gravely one to another: "Behold, verily, there is the woman of the scarlet letter; and, of a truth, moreover, there is the likeness of the scarlet letter running along by her side! Come, therefore, and let us fling mud at them!" (Hawthorne, 1852, pp. 92-3)

The gossipers are the children of the puritans. They trigger their gossip by utilizing the speech act of telling (there is the woman...). It serves the purpose of entertainment. The gossipees are the woman of the scarlet letter and her little daughter; both of the gossipees are triggered by the existential presupposition (definite noun phrases).

\section{Excerpt 9:}

"Even in the grave-yard, here at hand," answered the physician, continuing his employment. "They are new to me. I found them growing on a grave, which bore no tombstone, no other memorial of the dead man, save these ugly weeds that have taken upon themselves to keep him in remembrance. They grew out of his heart, and typify, it may be, some hideous secret that was buried with him, and which he had done better to confess during his lifetime." (Hawthorne, 1852, p. 120)

The gossiper is the physician. He triggers the gossip by means of the speech act of stating (they are new...) for the purpose of entertainment as he is talking with his friend Mr.

Dimmesdale. The gossipee is the dead man which is triggered by means of the existential presupposition (a definite noun phrase).

\section{Excerpt 10:}

"There goes a woman," resumed Roger Chillingworth, after a pause, "who, be her demerits what they may, hath none of that mystery of hidden sinfulness which you deem so grievous to be borne." (Hawthorne, 1852, p. 124)

The gossiper is Roger Chillingworth. The gossip is triggered by means of the speech act of telling (there goes a woman...). It is used to achieve social control as the talk is about the sin perpetrated by that woman. The gossipee is a woman actuated by an existential presupposition (a noun phrase).

\section{Discussion of Results}

In concern with the overall analysis of the data, the present section comes up with the findings of such analysis. As far as speech acts are concerned, the gossipers employ different kinds of speech acts in triggering the gossip, such as: telling, stating, and criticizing. Yet, it is found that the speech acts of telling and stating take their advantage over that of criticizing. They are used with equal frequencies having the percentage of $(0.4 \%)$. The following table makes it clear:

Arab World English Journal for Translation \& Literary Studies 
AWEJ for Translation \& Literary Studies Volume, 3 Number 3. August 2019

Gossiping in Hawthorne's The Scarlet Letter (1850)

Al- Murib

Table 1. The Occurrence of Speech Acts

\begin{tabular}{|c|c|c|}
\hline Speech Acts & Frequency & Percentage \\
\hline Telling & 4 & $0.4 \%$ \\
\hline Stating & 4 & $0.4 \%$ \\
\hline Criticizing & 2 & $0.2 \%$ \\
\hline
\end{tabular}

As for presupposition, the analysis shows that the existential presupposition, especially that of a noun phrase, is the only strategy that is employed by the gossipers to trigger gossip in all of the ten excerpts. Thus it has a percentage of $100 \%$.

\section{Conclusions}

Depending on the analysis of the data of the study, the following conclusions are introduced:

(1) Gossiping is an activity that is concerned with the affairs of a third party.

(2) The speech acts of telling, stating, and criticizing are employed to trigger gossip. They are used with different frequencies and percentages with these of telling and stating having four occurrences with the percentage of $(0.4 \%)$.

(3) Roughly speaking, there is a consensus between the type of the pragmatic strategy used to trigger gossip and the function that the gossiping employs. In other words, telling and stating, as pragmatic strategies are connected with serving the function of conveying information.

\section{About the author:}

Zahraa Adnan Fadhil Al-Murib is a member of staff in the Islamic University, Babylon, Iraq. She received her B.A. in English Language and Literature from College of Education, University of Babylon, 2013, and her M.A. in Linguistics from College of Education, University of Babylon, 2017. Her minor interest is stylistics. She has got a developing course in methods of teaching, Iraq, Babylon University, 2017. ORCiD ID: https://orcid.org/0000-0002-6470-6753

\section{References}

Al- Hindawi, F. \& Al- Khazaali, M. (Eds.). (2017). Linguistic Analysis of Literary Data. Hambrug: Anchor Academic Publishing.

Crawford, L. \& Novak, K. (2014). Individual and Society: Sociological Social Psychology. New York: Routledge.

Eckert, P. \& McConnell- Ginet, S. (2013). Language and Gender. New York: CUP.

Frost, C. (2016). Journalism Ethics and Regulation. New York: Routledge.

Galber, K. (2002). Speaking Back: The Free Speech Versus Hate Speech Debate. Philadelphia: John Benjamins Publishing Co.

Goldstein, A. P. (2002). The Psychology of Group Aggression. New York: John Wiley \& Sons, Inc.

Iterson, A.; Waddington, K.; \& Michelson, G. (2011). "Breaking the Silence: The Role of Gossip in Orgenizational Culture." In Ashkanasy, N. Wilerom, C. \& Peterson, M. (eds.) The Handbook of Orgenizational Culture and Climate. London: SAGE Publishing, Inc.

Arab World English Journal for Translation \& Literary Studies 
Hawthorne, N. (1952). The Scarlet Letter: A Romance. Leipzig: Bernard Tauchnitz. Hudson, G. (2000). Essential Introductory Linguistics. Michigan: Blackwell Publishers Inc. Marcus, P. (2010). The Search of the Good Life. London: Karnac Books, Ltd.

Mazid, B. (2014). CDA and PDA Made Simple. Cambridge: Cambridge Scholars Publishing. Ogden, S. G. (2017). The Church, Authority, and Foucault. New York: Routledge.

Rosnow, R. L. \& Fine, G. A. (1976). Rumor and Gossip: The Social Psychology of Hearsay. Michigan: MUP.

Shiffer, S. (2008). "From Meaning". In Noccetelli, S. \& Seay, G. (eds.) Philosophy of Language: The Central Topics. New Yourk: R \& L publishing, Inc.

Soeters, J. \& Iterson, A. (2002). "Blame and praise gossip in orgenizations". In Iterson, A.; Mastenbroek, W.; Newton, T.; \& Smith, D. (eds.) The Civilized Organization. Philadelphia: JBPC.

Tracy, K. \& Robles, J. (2013). Everyday Talk: Building and Reflecting Identities. New York: The Guilford Press.

Underwood, M. K. (2003). Social Aggression among Girls. London: The Guilford Press.

Zimmerman, B. (2000). Encyclopedia of Lesbian Histories and Cultures. London: Garland Publishing, Inc.

Arab World English Journal for Translation \& Literary Studies 